\title{
Prevalence, molecular detection, and virulence gene profiles of Campylobacter species in humans and foods of animal origin
}

\author{
Ashraf M. A. Barakat ${ }^{1}$, Khaled A. Abd El-Razik ${ }^{2}$ iD, Hassan A. Elfadaly ${ }^{1}$, Nagwa S. Rabie ${ }^{3}$ (i) Sabry A. S. Sadek ${ }^{1}$ (i) and
} Abdulaziz M. Almuzaini ${ }^{4}$

\begin{abstract}
1. Department of Zoonotic Diseases, National Research Centre, Dokki, Giza, Egypt; 2. Department of Animal Reproduction, National Research Centre, Dokki, Giza, Egypt; 3. Department of Poultry Diseases, National Research Centre, Dokki, Giza, Egypt; 4. Department of Veterinary Medicine, College of Agriculture and Veterinary Medicine, Qassim University, Buraydah, Saudi Arabia.

Corresponding author: Khaled A. Abd El-Razik, e-mail: khaled707@hotmail.com

Co-authors: AMAB: ashrafbarakat2@hotmail.com, HAE: hassanfadaly67@gmail.com, NSR: nagwasrabie@hotmail.com, SASS: drsabry.nrc@gmail.com, AMA: dr-almuzaini@hotmail.com

Received: 16-03-2020, Accepted: 29-05-2020, Published online: 24-07-2020
\end{abstract}

doi: www.doi.org/10.14202/vetworld.2020.1430-1438 How to cite this article: Barakat AMA, Abd El-Razik KA, Elfadaly HA, Rabie NS, Sadek SAS, Almuzaini AM (2020) Prevalence, molecular detection, and virulence gene profiles of Campylobacter species in humans and foods of animal origin, Veterinary World, 13(7): 1430-1438.

\begin{abstract}
Background and Aim: Campylobacteriosis is one of the most well-characterized bacterial foodborne infections worldwide that arise chiefly due to the consumption of foods of animal origin such as poultry, milk, and their products. The disease is caused by numerous species within the genus Campylobacter, but Campylobacter jejuni is the most commonly isolated species from established cases of human campylobacteriosis. This study was conducted to determine the prevalence and virulence of Campylobacter isolates from human, chicken, and milk and milk products in Egypt.

Materials and Methods: A total of 1299 samples (547 chicken intestine and liver, 647 milk and milk products, and 105 human stool) were collected and microbiologically investigated, confirmed by multiplex polymerase chain reaction (PCR) targeting the 23S rRNA, hipO, and glyA genes specific for Campylobacter spp., C. jejuni, and Campylobacter Coli, respectively, followed by virulence genes (Campylobacter adhesion to fibronectin F [cadF] and $c d t B$ ) detection using PCR.

Results: About $38.09 \%, 37.84 \%$, and $8.5 \%$ of human stool, chicken, and milk and milk product samples, respectively, were bacteriologically positive, with a total of 302 Campylobacter isolates. All isolates were molecularly confirmed as Campylobacter spp. (100\%) where 285 isolates $(94.37 \%)$ were identified as C. jejuni and 17 isolates $(5.62 \%)$ as C. coli. Regarding the virulence pattern, all isolates $(100 \%)$ carried $c a d F$ gene while cytolethal distending toxin B gene was definite in 284/302 isolates (94\%), concisely, 282/285 (98.94\%) C. jejuni isolates, and in 2/17 (11.76\%) C. coli isolates.

Conclusion: The widespread presence of these highly virulent Campylobacter, especially C. jejuni, proofs the urgent need for the implementation of stringent control, public health, and food protection strategies to protect consumers from this zoonotic pathogen. The availability of information about pathogen virulence will enable enhanced local policy drafting by food safety and public health officials.
\end{abstract}

Keywords: Campylobacter, Egypt, food, human stool, multiplex polymerase chain reaction, virulence genes.

\section{Introduction}

Campylobacteriosis is a serious zoonotic gastrointestinal disease worldwide, and most cases are mainly caused by Campylobacter jejuni. Poultry plays an important role in the transmission of campylobacteriosis to humans [1]. C. jejuni colonizes the chicken gut primarily in the cecum and small intestine but also colonizes the liver and spleen [2]. Thus, the intestinal tract of chickens supplies a reservoir of Campylobacter that may spread through fecal material at farms or during processing [3]. Human Campylobacter infection may be due to either the consumption of undercooked meat or the cross-contamination of

Copyright: Barakat, et al. Open Access. This article is distributed under the terms of the Creative Commons Attribution 4.0 International License (http://creativecommons.org/licenses/ by/4.0/), which permits unrestricted use, distribution, and reproduction in any medium, provided you give appropriate credit to the original author(s) and the source, provide a link to the Creative Commons license, and indicate if changes were made. The Creative Commons Public Domain Dedication waiver (http:// creativecommons.org/publicdomain/zero/1.0/) applies to the data made available in this article, unless otherwise stated. ready-to-eat food during preparation or storage [4]. Worldwide, C. jejuni is responsible for $85 \%$ of foodborne Campylobacter enteritis in humans and is the most frequently isolated Campylobacter species recovered from poultry, while the remaining cases are primarily attributed to Campylobacter coli [5]. Campylobacter species are the main cause of bacterial gastrointestinal disease campylobacteriosis, which causes diarrhea, sometimes dysentery syndrome, and cramps, fever, and pain in developing countries. In particular, C. jejuni and C. coli are accountable for campylobacteriosis [6].

The isolation of campylobacters using the culture method is considered the gold standard for campylobacteriosis disease diagnosis; however, it is time-consuming and laborious because of the fastidious nature of campylobacters [7]. In addition, the differentiation of species using biochemical assays is difficult due to the phylogenetic relatedness of $C$. jejuni and C. coli species [8]. Thus, molecular-based assays, such as polymerase chain reaction (PCR) and sequencing, can 
enable easy, rapid, and specific detection and epidemiological applications [9]. For this purpose, various genes have been used [10].

Several genes have been linked to Campylobacter virulence, but the most important are cytolethal distending toxin B $(c d t B)$, which disrupts mucosal barriers by causing host cell death, Campylobacter adhesion to fibronectin $\mathrm{F}(\mathrm{cad} F)$, and the heat survival and stress response proteins $h t r B$ and $c l p P$, which are important for survival $[10,11]$. The disease severity depends on the virulence of the strain and on the host's immune condition. $c a d F$ is one of the reference virulence genes that encode a protein involved in the invasion and adhesion of C. jejuni [12], and this gene is present at a high level in C. jejuni isolates [13].

Despite the increased recovery of Campylobacter as a foodborne pathogen, the specific virulence and pathogenic mechanisms by which microaerophilic Campylobacter species cause infection are still poorly understood [14]. The putative virulence factor for adhesion and invasion of epithelial cells, toxin production, and flagellar motility are thought to be important virulence mechanisms [15]. However, different studies have indicated that different virulence markers play a role in the colonization, adherence, and invasion of Campylobacter spp. in animals and humans [15].

The aim of this study was to investigate the prevalence of Campylobacter spp. using conventional and molecular tools and to determine the virulence gene profile of Campylobacter spp. in humans and foods of animal origin in Egypt.

\section{Materials and Methods}

\section{Ethical approval}

All aspects of the study were performed in accordance with national ethics regulations and approved by the National Research Ethical Committee, National Research Centre, Giza, Egypt (Ethical Approval no 16220). Written consent was taken from patients before collecting stool samples.

\section{Sample collection}

A total of 1299 samples (Table-1) from chickens $(n=547)$, milk and milk products $(n=647)$ from various markets, and human stool $(\mathrm{n}=105)$ were collected randomly from different governorates in Egypt (Cairo, Giza, Fayoum, and Qalyubia) from January 2018 to December 2018. The human stool specimens were collected at random from people with diarrhea who were admitted to different laboratories, people in contact with backyard chickens and slaughterhouses and from diarrheic children admitted to hospitals for kids in Egypt. Ten grams of each sample (chicken intestine and liver, milk and milk products, and human stool) were collected in a sterile sample collection vial and transferred to the laboratory. All samples were immediately stored at $4{ }^{\circ} \mathrm{C}$ and processed to isolate campylobacters.

\section{Isolation and identification of Campylobacter}

A loop of each sample was homogenized in sterile thioglycollate broth (Oxoid). Broth samples were incubated at $42^{\circ} \mathrm{C}$ for $48 \mathrm{~h}$ in a microaerobic atmosphere using an anaerobic jar with CampyGen sachets, which generates $10 \% \mathrm{CO}_{2}, 5 \% \mathrm{O}_{2}$, and $85 \% \mathrm{~N}_{2}$. A loopful of enrichment broth was streaked onto mCCDA plates (Oxoid) and incubated under microaerobic condition at $42^{\circ} \mathrm{C}$ for $48 \mathrm{~h}$ followed by microscopic examination to examine their characteristic motility utilizing phase contrast microscope after staining by Gram's stain presenting seagull appearance. All isolates were subjected to biochemical tests, such as catalase, oxidase, urease, nitrate reduction, indole acetate hydrolysis, and hippurate hydrolysis tests and susceptibility tests to cephalothin and nalidixic acid by the disk diffusion method [16].

\section{Molecular characterization of Campylobacter species}

\section{DNA extraction}

DNA was extracted by the heating and snap chilling method [17]. Two to three colonies of fresh bacterial growth were collected from culture medium, suspended in nuclease-free demonized water, and heated at $95^{\circ} \mathrm{C}$ for $10 \mathrm{~min}$. The samples were cooled immediately and centrifuged for $5 \mathrm{~min}$ at room temperature. The supernatant was separated and $3 \mu 1$ was used as the DNA template.

\section{Confirmation of Campylobacter spp., C. jejuni, and C. coli isolates by multiplex PCR}

A multiplex PCR reaction was used for the confirmation of biochemically identified Campylobacter spp. through targeting $23 S$ rRNA specific for Campylobacter spp., hipO gene specific for C. jejuni, and glyA gene specific for C. coli (Table-2) [18-21]. Primers were utilized in a $25 \mu \mathrm{l}$ reaction containing $12.5 \mu \mathrm{l}$ of $2 \times$ ViRed Taq Master Mixture (Cat. no. CLMM01, Vivantis Technologies, Malaysia), $1 \mu 1$ of each primer ( $20 \mathrm{pmol}), 5.5 \mu \mathrm{l}$ of water, and $3 \mu \mathrm{l}$ of template. Cycling conditions begin with initial

Table-1: Samples collected from different localities in Egypt.

\begin{tabular}{|c|c|c|c|c|c|c|c|}
\hline \multirow[t]{2}{*}{ Site of samples } & \multirow[t]{2}{*}{ Number of samples } & \multicolumn{2}{|c|}{ Chicken samples } & \multicolumn{3}{|c|}{ Milk and milk products } & \multirow[t]{2}{*}{ Human stoo } \\
\hline & & Intestine & Liver & Milk & Cheese & Yoghurt & \\
\hline Giza & 400 & 165 & 60 & 77 & 40 & 41 & 17 \\
\hline Fayoum & 319 & 115 & 10 & 65 & 52 & 47 & 30 \\
\hline Cairo & 266 & 60 & 10 & 65 & 40 & 59 & 32 \\
\hline Qalyubia & 314 & 80 & 47 & 67 & 48 & 46 & 26 \\
\hline Total & 1299 & 420 & 127 & 274 & 180 & 193 & 105 \\
\hline
\end{tabular}


denaturation at $95^{\circ} \mathrm{C}$ for $6 \mathrm{~min}$, followed by 35 cycles of denaturation at $95^{\circ} \mathrm{C}$ for $30 \mathrm{~s}$, annealing at $59^{\circ} \mathrm{C}$ for $30 \mathrm{~s}$, and extension at $72^{\circ} \mathrm{C}$ for $30 \mathrm{~s}$ with a single final extension step at $72^{\circ} \mathrm{C}$ for $10 \mathrm{~min}$. The PCR products were separated by electrophoresis on $1 \%$ agarose gel.

\section{Virulence gene characterization of Campylobacter isolates}

The confirmed isolates of Campylobacter species were characterized for in vitro detection of virulence genes by PCR for two well-known virulence genes encoding the $c a d F[20]$ and $c d t B$ genes [14]. The details of the primers for the target virulence genes are described in Table-2. Cycling conditions were as previous with annealing at $45^{\circ} \mathrm{C}$ for $c a d F$ gene and $57^{\circ} \mathrm{C}$ for $c d t B$ gene.

\section{Phylogenetic tree construction}

The positive PCR products targeting the $c a d F$ gene of two C. jejuni samples (CJ1 and CJ2) were sequenced by MACROGEN Company (Korea) on 3730XL sequencers (Applied Biosystems, USA). The accuracy of the data was confirmed by two-directional sequencing with the forward and reverse primers used in PCR. The nucleotide sequences obtained in this study were analyzed using the programs BioEdit 7.0.4.1 and Muscle (https://www.ebi.ac.uk/Tools/msa/ muscle/). The resulting sequences were aligned with the cadF virulence gene of Campylobacter spp. reference sequences (Table-3) using neighbor-joining analysis of the aligned sequences implemented in the program CLC Genomics Workbench 3.

\section{Results}

\section{Identification of Campylobacter species}

In this investigation, samples were collected from Giza, Fayoum, Cairo, and Qalyubia in Egypt for the isolation of Campylobacter spp. from chicken, milk, milk products, and human stool. Campylobacter spp. were isolated from $37.84 \%$ of chickens, $8.5 \%$ of milk and milk product samples, and $38.09 \%$ of human stool samples with a total of 302 (23.24\%) Campylobacter spp. isolates (Table-4).

\section{Confirmation of Campylobacter spp., C. jejuni, and} C. coli isolates by multiplex PCR

The 302 biochemically identified Campylobacter isolates were molecularly confirmed by the amplification of $23 S$ rRNA gene of Campylobacter spp., the hipO gene specific to C. jejuni, and the glyA gene specific to $C$. coli. All the 302 isolates were confirmed as Campylobacter (Figure-1), of which $94.37 \%$ as C. jejuni and $5.62 \%$ as C. coli (Figures-2 and 3, Table-4).

In detail, $69.35 \%, 57.5 \%$, and $63.33 \%$ of isolates from chicken, milk and milk product, and human stool samples were confirmed as $C$. jejuni while $6.76 \%$ and 5.62 of chicken and human stools samples as C. coli, respectively (Table-4).

\section{Virulence determinants}

With regard to the virulence pattern, all isolates carried the virulence associate gene cadF (100\%), while $c d t B$ gene was positive in 284 out of the 302 isolates (94\%). Briefly, 282 out of 285 (98.94\%) of C. jejuni isolates and 2 out of $17(11.76 \%)$ of $C$. coli isolates were positive for $c d t B$ gene (Figure-4a and $\mathrm{b}$ ).

\section{Nucleotide sequence accession numbers}

Two sequences ( $C$. jejuni cadF gene) used in this study (CJ1 and CJ2) have been deposited in the GenBank database under the accession nos. MN103381-MN103382. Phylogenetic analysis confirmed that the two isolates were $C$. jejuni with

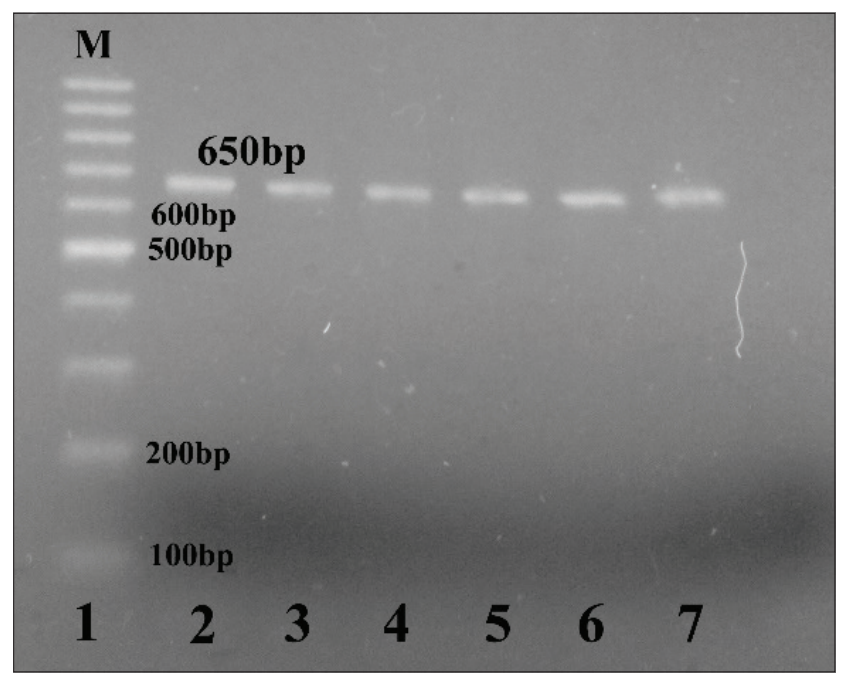

Figure-1: Amplification of the 23S rRNA gene of Campylobacter spp. positive amplification appeared at 650 bp, lane 1: 100 bp ladder, lane 2: The positive control, lanes 3-7: Positive for Campylobacter spp.

Table-2: Primer sets for PCR amplification of the four target genes of Campylobacter species.

\begin{tabular}{|c|c|c|c|c|}
\hline Target gene & Primer & Primer sequence $\left(5^{\prime} \rightarrow 3^{\prime}\right)$ & Size (in bp) & References \\
\hline Campylobacter spp. $23 S$ rRNA & $\begin{array}{l}\text { CB1 } \\
\text { CB2 }\end{array}$ & $\begin{array}{l}\text { TATACCGGTAAGGAGTGCTGGAG } \\
\text { ATCAATTAACC TTCGAGCACCG }\end{array}$ & 650 & [19] \\
\hline Campylobacter jejuni hipO & $\begin{array}{l}\mathrm{CJF} \\
\mathrm{CJR}\end{array}$ & $\begin{array}{l}\text { ACTTCTTATTGCTTGCTGC } \\
\text { GCCACAACAAGTAAAGAAGC }\end{array}$ & 323 & [19] \\
\hline Campylobacter coli glyA & $\begin{array}{l}\text { CCF } \\
\text { CCR }\end{array}$ & $\begin{array}{l}\text { GTAAAACCAAAGCTTATCGTG } \\
\text { TCCAGCAATGTGTGCAATG }\end{array}$ & 126 & {$[18]$} \\
\hline $\begin{array}{l}\text { Campylobacter adherence gene } \\
(\mathrm{cadF})\end{array}$ & $\begin{array}{l}\text { cad } F \\
\text { cad R }\end{array}$ & $\begin{array}{l}\text { TTGAAGGTAATTTAGATATG } \\
\text { CTAATACCTAAAGTTGAAAC }\end{array}$ & 400 & {$[20]$} \\
\hline $\begin{array}{l}\text { Cytolethal distending toxin } \\
\text { subunit B gene }(c d t B)\end{array}$ & $\begin{array}{l}\text { CdtB-F } \\
\text { CdtB-R }\end{array}$ & $\begin{array}{l}\text { GTTGGCACTTGGAATTGGAAGGC } \\
\text { GTTAAAATCCССTGCTATCAACCA }\end{array}$ & 495 & {$[21]$} \\
\hline
\end{tabular}

$\mathrm{PCR}=$ Polymerase chain reaction 
Available at www.veterinaryworld.org/Vol.13/July-2020/25.pdf

Table-3: Details of Campylobacter jejuni isolates used in the present study and available in GenBank.

\begin{tabular}{|c|c|c|c|c|c|c|}
\hline S. No. & Organism & Strain & Host & Isolation source & Country & Access. No. \\
\hline 1 & Campylobacter jejuni & $\mathrm{CJ} 1$ & Broiler chicken & Intestine & Egypt & MN103381 \\
\hline 2 & Campylobacter jejuni & $\mathrm{CJ} 2$ & Broiler chicken & Liver & Egypt & MN103382 \\
\hline 3 & $\begin{array}{l}\text { Campylobacter jejuni } \\
\text { subsp. jejuni }\end{array}$ & D42a & Chicken & Caecum & USA & СР007751 \\
\hline 4 & Campylobacter jejuni & RM1285 & Chicken & Breast exudate & USA & СР012696 \\
\hline 5 & Campylobacter jejuni & YQ2210 & Turkey & --- & USA & СР017859 \\
\hline 6 & Campylobacter jejuni & 104 & Chicken & ---- & Brazil & СР023343 \\
\hline 7 & Campylobacter jejuni & CFSAN032806 & Chicken & Breast & USA & СР023543 \\
\hline 8 & Campylobacter jejuni & FDAARGOS_421 & Chicken & Carcass & USA & СР023866 \\
\hline 9 & Campylobacter jejuni & NCTC 12664 & Chicken & ---- & $\begin{array}{l}\text { United } \\
\text { Kingdom }\end{array}$ & СР028912 \\
\hline 10 & Campylobacter jejuni & FORC_083 & Chicken & Meat & South Korea & CP028933 \\
\hline 11 & $\begin{array}{l}\text { Campylobacter jejuni } \\
\text { subsp. jejuni }\end{array}$ & CLB104 & Chicken & Liver & $\begin{array}{l}\text { United } \\
\text { Kingdom }\end{array}$ & СР034393 \\
\hline 12 & $\begin{array}{l}\text { Campylobacter jejuni } \\
\text { subsp. jejuni }\end{array}$ & $00-2425$ & Human & Stool & Canada & СР006729 \\
\hline 13 & Campylobacter jejuni & CJ074CC443 & Human & ---- & Finland & СР012216 \\
\hline 14 & $\begin{array}{l}\text { Campylobacter jejuni } \\
\text { subsp. jejuni }\end{array}$ & RM3196 & Human & --- & South Africa & СР012690 \\
\hline 15 & Campylobacter jejuni & FDAARGOS_263 & Human & Stool & USA & СР022077 \\
\hline 16 & Campylobacter jejuni & FDAARGOS_422 & Human & ---- & USA & СР023867 \\
\hline 17 & $\begin{array}{l}\text { Campylobacter jejuni } \\
\text { subsp. jejuni }\end{array}$ & huA17 & Human & Stool & Germany & СР028372 \\
\hline 18 & $\begin{array}{l}\text { Campylobacter jejuni } \\
\text { subsp. jejuni }\end{array}$ & NCTC10983 & Human & Blood & $\begin{array}{l}\text { United } \\
\text { Kingdom }\end{array}$ & LR134511 \\
\hline
\end{tabular}

Table-4: Prevalence of Campylobacter genus in the examined samples by conventional and molecular methods.

\begin{tabular}{|c|c|c|c|c|c|c|}
\hline \multirow[t]{2}{*}{ Type of samples } & \multicolumn{2}{|c|}{$\begin{array}{c}\text { Incidence by } \\
\text { conventional method }\end{array}$} & \multicolumn{2}{|c|}{$\begin{array}{l}\text { Incidence of } C \text {. jejuni } \\
\text { by multiplex PCR }\end{array}$} & \multicolumn{2}{|c|}{$\begin{array}{c}\text { Incidence of } C \text {. coli } \\
\text { by multiplex PCR }\end{array}$} \\
\hline & $\mathbf{n}$ & $\%$ & $\mathbf{n}$ & $\%$ & $\mathbf{n}$ & $\%$ \\
\hline Chickens & $207 / 547$ & 37.84 & $193 / 207$ & 93.23 & $14 / 207$ & 6.76 \\
\hline Intestine & $160 / 420$ & 38.09 & $158 / 160$ & 98.75 & $2 / 160$ & 1.25 \\
\hline Liver & $47 / 127$ & 37 & $35 / 47$ & 74.46 & $12 / 47$ & 25.5 \\
\hline Milk and milk products & $55 / 647$ & 8.5 & $55 / 55$ & 100 & $0 / 55$ & 0 \\
\hline Raw milk & $14 / 274$ & 5.1 & $14 / 14$ & 100 & $0 / 14$ & 0 \\
\hline Cheese & $14 / 180$ & 7.77 & $14 / 14$ & 100 & $0 / 14$ & 0 \\
\hline Yoghurt & $27 / 193$ & 13.98 & $27 / 27$ & 100 & $0 / 27$ & 0 \\
\hline Human stool & $40 / 105$ & 38.09 & $37 / 40$ & 92.5 & $3 / 40$ & 7.5 \\
\hline Total & $302 / 1299$ & 23.24 & $285 / 302$ & 94.37 & $17 / 302$ & 5.62 \\
\hline
\end{tabular}

C. jejuni=Campylobacter jejuni, C. coli= Campylobacter coli, PCR=Polymerase chain reaction

homology results of $99-100 \%$. In the phylogenetic tree, all Egyptian isolates formed two separate clusters (Figure-5). Phylogenetic analysis showed that CJ1 (MN103381) and CJ2 (MN103382), which were isolated from the intestine and liver of chickens, respectively, had typical homology with $C$. jejuni isolated from either chicken or human (Figure-5).

\section{Discussion}

In the current study, Campylobacter spp. were isolated from $37 \%$ to $38.09 \%$ of the liver and intestine of chickens, respectively. Similar isolation rate $(28.3 \%)$ from cloacal swabs was reported in Egypt [22]. Comparable isolation rates (31.9\% and 39.2\%) were reported in Vietnam [23] and Estonia [24], respectively. Reduced isolation rate (16.83\%) was reported by Abushahba et al. [25]. The reported prevalence rate of Campylobacter spp. is higher in the previous studies than in this study, for instance, $41.2 \%$ and $48.5 \%$ in Egypt $[22,26]$ and $58 \%$ in Brazil [27]. The aforementioned high isolation rates could be attributed to the extensive type of chicken management that increases the exposure of birds to Campylobacter infection through insects, rodents, contaminated water, and poor housing hygiene [28]. In addition, high isolation rates of $82.9 \%$ in Italy and $51.5 \%$ in Nigeria from chicken cloacal swabs, respectively, were reported [29,30], which could be a result of using only conventional methods.

The variation in the isolation rate of Campylobacter spp. between different studies could be attributed to the age of the examined chickens [31] and the difference in the sanitation levels, while handling and processing chickens, the type and site of the examined samples, the sampling season, the laboratory methodologies employed for isolation, husbandry 


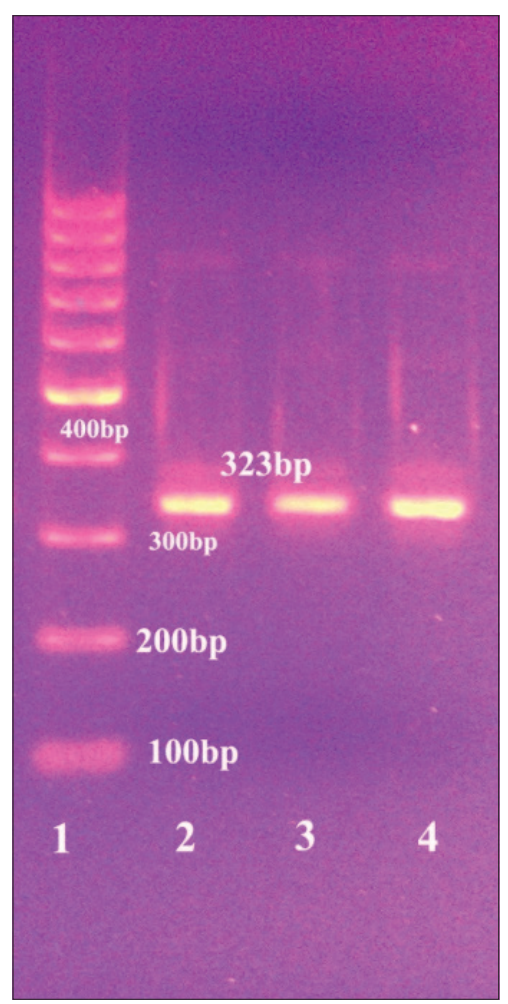

Figure-2: Amplification of the hipO gene of Campylobacter jejuni, positive amplification appeared at $323 \mathrm{bp}$, lane 1: 100 bp ladder, lane 2: The positive control C. jejuni, lanes 3 and 4: Positive for C. jejuni.

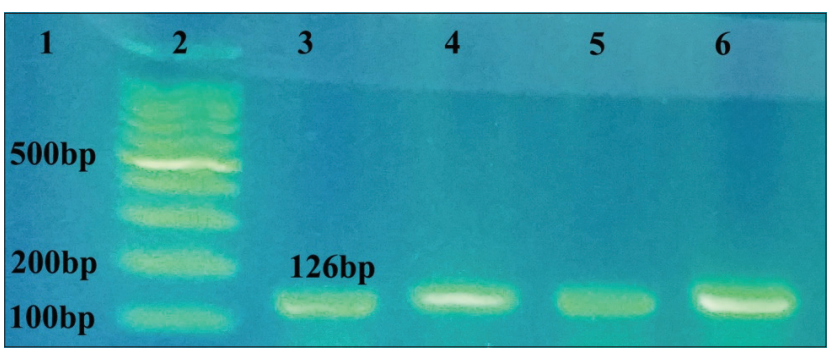

Figure-3: Amplification of the glyA gene of Campylobacter coli, positive amplification appeared at $126 \mathrm{bp}$, lane 1: 100 bp ladder and lane 2: The positive control C. coli, lanes 4-6: Positive for $C$. coli. and management, and the production system have the greatest impact on the prevalence rate of campylobacters [32].

Cattle play an important role in human campylobacteriosis. There are cattle-related outbreaks that indicate that raw milk and dairy products are the second most frequent sources of infection. Direct contamination of milk may occur through feces or as a consequence of mastitis [33]. In the current study, Campylobacter spp. was isolated from $8.5 \%$ of milk and milk products samples $(5.1 \%, 7.77 \%$, and $13.98 \%$ of raw milk, cheese, and yoghurt samples, respectively). The higher percentage of Campylobacter in milk products than in raw milk is explained by the contamination of milk products because of unhygienic conditions during the preparation of milk products. A similar isolation rate of Campylobacter from raw milk (7.2\%) was reported in Turkey [1]. Relatively low prevalence rates of $2.91 \%$ and $2.32 \%$ were reported [17,34], respectively. In contrast, high prevalence rates of Campylobacter in milk at $17.2 \%, 20 \%$, and $66.8 \%$ were reported [35-37]. Here, Campylobacter spp. were isolated from $7.77 \%$ and $13.98 \%$ of cheese and yoghurt samples, respectively. Similarly, a prevalence rate of $5.0 \%$ from cheese was reported by Giacometti et al. [38]. In the contrary, Campylobacter was absent from milk product samples in some reports [17,39]. This emphasizes the importance of milk and dairy products as a potential source of Campylobacter.

In general, Campylobacter is the most common bacterium that induces gastroenteritis in humans globally and can be fatal to young children, geriatric patients, and immunocompromised patients [40]. In the current study, an isolation rate of $38.09 \%$ was reported in stool samples from humans. These results were concurrent with the isolation rate $(33.33 \%)$ detected by Rouby et al. [41] in Egypt but were higher than those (27.5\%) detected by Abushahba et al. [25]

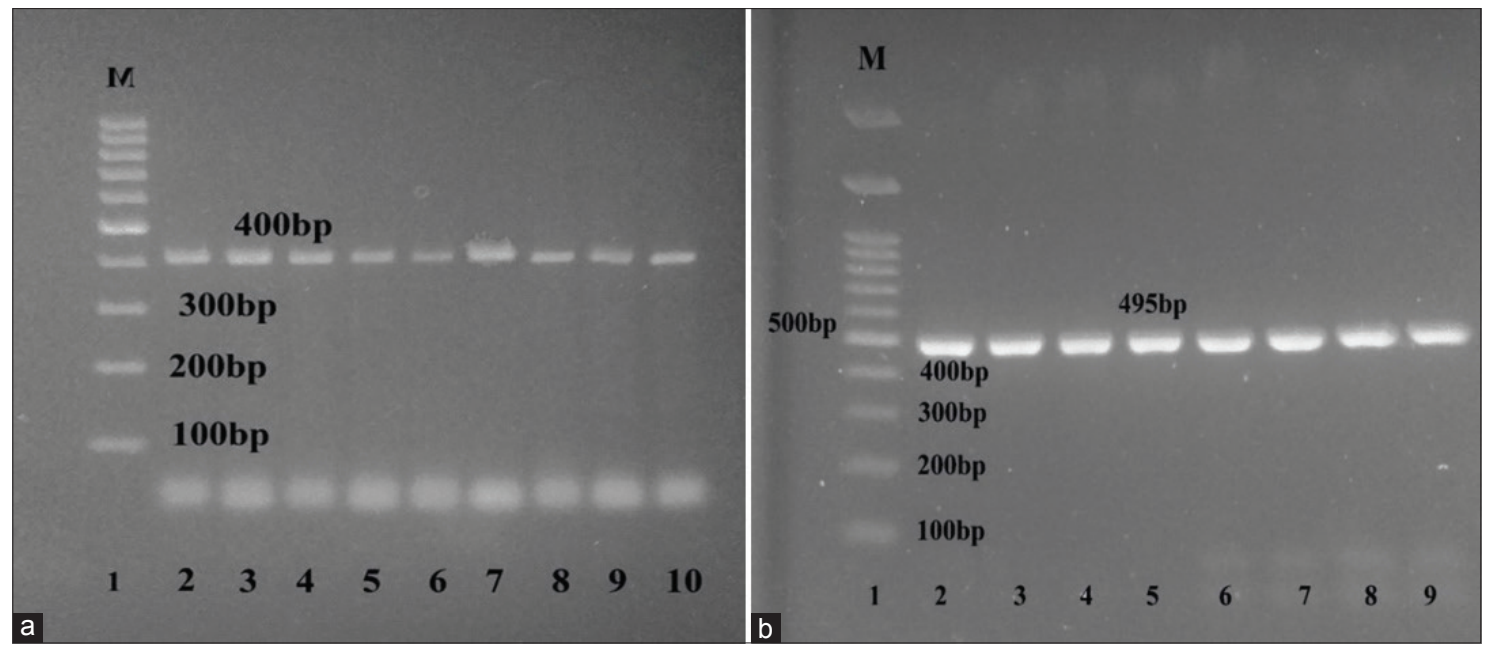

Figure-4: Agarose gel electtrophoresis of polymerase chain reaction products obtained with primers for, (a) the cadF gene. Lane 1, 100 bp ladder; 2-10, 400 bp fragment of the cadF gene of Campylobacter jejuni and Campylobacter coli. (b) The cdtB gene. Lane 1, 100 bp ladder; 2-9, 495-bp fragment of the cdtB gene of $C$. jejuni and $C$. coli. 


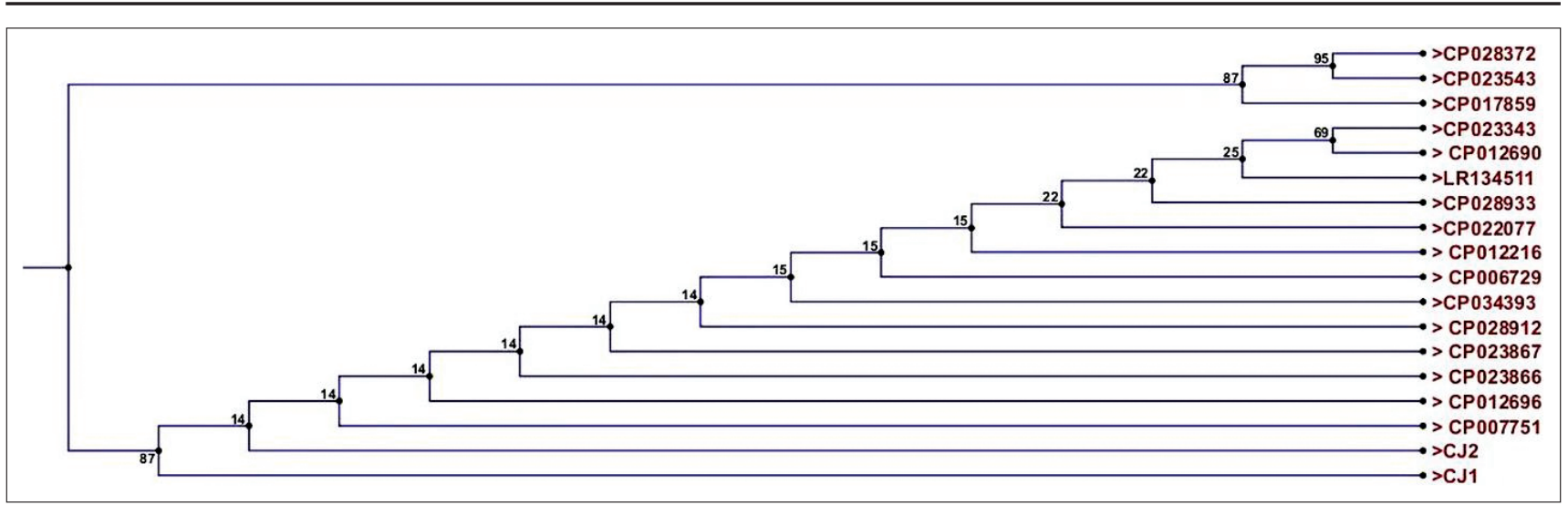

Figure-5: Phylogenetic relationship of selected strains of Campylobacter jejuni from poultry, milk and milk products, and human; the accession numbers of the isolates used are given.

in Egypt. The high percentage detected in our study could be attributed to the inclusion of stool samples primarily obtained from gastroenteritis-infected individuals rather than investigating the disease in the general population.

PCR is still rapid, specific, sensitive, and of substantial interest for the recognition and verification of Campylobacter species. Thus, PCR is a dependable substitute for conventional culture [3,42]. Molecular methods were used to confirm the detected Campylobacter species and to differentiate between C. jejuni and C. coli, as the discrimination of $C$. jejuni and $C$. coli is considered difficult because it depends only on a single phenotypic test [8]. Therefore, here, multiplex PCR was used to identify the isolated Campylobacter spp. (302 isolates) by targeting the $23 S$ rRNA specific for Campylobacter spp., hipO gene of $C$. jejuni, and the glyA gene of $C$. coli. The multiplex PCR results confirmed all the 302 biochemically identified isolates as Campylobacter spp. of which 285 isolates as $C$. jejuni $(94.37 \%)$ and $5.62 \%$ as C. coli. A total percentage of $69.35 \%, 57.5 \%$, and $63.33 \%$ of isolates from chicken, milk and milk product, and human stool samples were confirmed as C. jejuni while $6.76 \%$ and 5.62 of chicken and human stools samples as C. coli, respectively.

One hundred and ninety-three out of 207 Campylobacter isolates $(93.23 \%)$ recovered from chicken samples were identified as $C$. jejuni using multiplex PCR. Similar results using PCR, where C. jejuni was the predominant isolate and reached prevalence rates as high as $87.5 \%, 90 \%$, and $89 \%$ in frozen chicken carcasses as reported in Egypt [3], in Great Britain [43], and in Vietnam [23], respectively. The predominance of $C$. jejuni may be due to its ability to survive high and low temperatures, low $\mathrm{pH}$, and dry conditions [44]. This was contrary to the findings in Egypt [22,26] and in Argentina [45], those reported C. jejuni as the only species isolated and molecularly identified from chickens. Moreover, 14 out of 207 Campylobacter isolates $(6.76 \%)$ recovered from chicken samples were identified as $C$. coli using multiplex PCR. Only a few reports are available regarding
C. coli as the predominant isolate in Egypt [42] and Greece [46]. This may be due to the type of feed ration because $C$. jejuni does not frequently colonize birds receiving plant protein-based feed [46].

A total of 55 Campylobacter isolates recovered from milk and milk products were identified as C. jejuni (100\%) using multiplex PCR. This was concurrent with the findings in Egypt [17], indicating that this species is distributed widely in the study areas. Similar results reported that $C$. jejuni was the predominant isolate (85.7\%) in Turkey [1].

A total of 37 out of 40 Campylobacter isolates recovered from human stool were identified as C. jejuni $(92.5 \%)$ and 3 out of 40 isolates as C. coli $(7.5 \%)$ using multiplex PCR. The isolation rates of $C$. jejuni that were higher than those of $C$. coli from Campylobacter-positive stool samples were in relative agreement with that $(61.7 \%)$ of Sainato et al. [40] and with higher prevalence than those (27.5\% and $8.4 \%)$ of Abushahba et al. [25] and Omara et al. [47] in Egypt, respectively. The high prevalence observed in our study may be a result of collecting samples from humans originating from villages, where basic hygienic standards and precautions for the contact and handling of live poultry are usually not adopted. This was in contrast with the findings of Rouby et al. [41] who reported that PCR revealed that all isolates were C. jejuni. Moreover, C. coli was the predominant isolate, as high as $1.11 \%$ and 3\%, as reported in Egypt [25] and in Poland [48], respectively.

The minimal infective dose of $C$. jejuni is very low, which indicates that $C$. jejuni is highly virulent, and a very small number of bacterial cells could cause infection in humans. The virulence of Campylobacter species is associated with flagellar motility, adhesion, invasion, and production of cytolethal distending toxins [49]. Several genes have been linked to Campylobacter virulence that might contribute to human infection and colonization of chickens [13]. The most important are $c d t B$, which disrupts mucosal barriers by causing host cell death, and $c a d F$ [26]. The detection of the $c a d F$ gene in all $C$. jejuni and $C$. coli 
isolates $(100 \%)$ from chickens was in agreement with the findings from the previous reports [50,51]; similarly, the results of this study were consistent with the previous results regarding the presence of $C$. coli from humans [51]. However, a higher percentage was identified in this study than in other reports $(41.6 \%$ and $8 \%$ ), among all $C$. jejuni isolates $[1,50]$. The high prevalence rate $(100 \%)$ of the $c a d F$ gene in the present study shows that many strains originating from poultry, milk and milk products have potential pathogenic properties toward humans, as reported by Frasao et al. [13] and Kalantar et al. [19].

According to Gonzalez-Hein et al. [52], CdtB cytotoxin subunit is encoded by $c d t B$ gene that plays an essential role in exerting a toxic effect on cells. In the present study, Campylobacter cytotoxic factor $(c d t B)$ was confirmed in $98.94 \%$ of $C$. jejuni isolates and $11.76 \%$ of $C$. coli isolates. The occurrence of $c d t B$ from chicken isolates in this study was higher than that of Abu-Madi et al. [50] and ELSayed et al. [26] who reported $6.7 \%$ and $0 \%$, respectively, but less than that of Modi et al. [17] that reported the presence of $c d t B$ gene in all isolates from bovine and swine tissue. Our findings confirm the relatively higher prevalence of $c d t B$ gene in $C$. jejuni in comparison to C. coli. This is in parallel with that of Wysok et al. [53].

\section{Conclusion}

Our study demonstrated the widespread existence of highly virulent Campylobacter isolates, especially $C$. jejuni in chicken, milk and milk product, and human, confirming that this species is a serious infection hazard and public health concern. Moreover, this study emphasizes the urgent need for the implementation of stringent control, public health, and food protection strategies to protect consumers from this zoonotic pathogen. The availability of information about pathogen virulence will enable enhanced local policy drafting by food safety and public health officials and will increase the awareness of this medically and economically important pathogen.

\section{Authors' Contributions}

AMAB and NSR designed the study, conducted the experiments, and revised the manuscript; $\mathrm{HAE}$ and SASS conducted bacterial isolation and identification. KAAE and AMA performed the molecular identification and characterization and wrote the manuscript. All authors read and approved the final manuscript for publication.

\section{Acknowledgments}

The authors sincerely thank the National Research Center, Egypt, for funding this study by an internal grant (11090403).

\section{Competing Interests}

The authors declare that they have no competing interests.

\section{Publisher's Note}

Veterinary World remains neutral with regard to jurisdictional claims in published institutional affiliation.

\section{References}

1. Elmali, M. and Can, H.Y. (2019) Antimicrobial susceptibility and virulence-associated genes in Campylobacter isolates from milk and wastewater in Hatay, Turkey. Ciência Rural, 49(5): e20180227.

2. Lamb-Rosteski, J.M., Kalischuk, L.D., Inglis, G.D. and Buret, A.G. (2008) Epidermal growth factor inhibits Campylobacter jejuni-induced claudin-4 disruption, loss of epithelial barrier function, and Escherichia coli translocation. Infect. Immun., 76(8): 3390-3398.

3. Abd El-Aziz, D. and Abd-Allah, S. (2017) Incidence of Campylobacter species in wholesale chicken carcasses and chicken meat products in Assiut city, Egypt. Int. Food Res. $J ., 24(6):$ 2660-2665.

4. Hafez, A., Younis, G., El-Shorbagy, M. and Awad, A. (2018) Prevalence, cytotoxicity and antibiotic susceptibility of Campylobacter species recovered from retail chicken meat in Mansoura, Egypt. Afr. J. Microbiol. Res., 12(22): 501-507.

5. Wagenaar, J.A., French, N.P. and Havelaar, A.H. (2013) Preventing Campylobacter at the source: Why is it so difficult? Clin. Infect. Dis., 57(11): 1600-1606.

6. EFSA European Food Safety Authority Report. (2010) Analysis of the baseline survey on the prevalence of Campylobacter in broiler batches and of Campylobacter and Salmonella on broiler carcasses in the EU, 2008-Part A: Campylobacter and Salmonella prevalence estimates. EFSAJ, 8(3): 1503.

7. Li, L., Mendis, N., Trigui, H., Oliver, J.D. and Faucher, S.P. (2014) The importance of the viable but non-culturable state in human bacterial pathogens. Front. Microbiol., 5: 258.

8. Miller, R.S., Miller, W.G., Behringer, M., Hariharan, H., Matthew, V. and Oyarzabal, O.A. (2010) DNA identification and characterization of Campylobacter jejuni and Campylobacter coli isolated from caecal samples of chickens in Grenada. J. Appl. Microbiol., 108(3): 1041-1049.

9. Vinueza-Burgos, C., Wautier, M., Martiny, D., Cisneros, M., Van Damme, I. and De Zutter, L. (2017) Prevalence, antimicrobial resistance and genetic diversity of Campylobacter coli and Campylobacter jejuni in Ecuadorian broilers at slaughter age. Poult. Sci., 96(7): 2366-2374.

10. Shams, S., Bakhshi, B. and Moghadam, T. (2016) In sil$i c o$ analysis of the $c a d F$ gene and development of a duplex polymerase chain reaction for species-specific identification of Campylobacter jejuni and Campylobacter coli. Jundishapur J. Microbiol., 9(2): e29645.

11. Elhadidy, M., Miller, W.G., Arguello, H., ÁlvarezOrdóñez, A., Duarte, A. and Dierick, K. (2018) Genetic basis and clonal population structure of antibiotic resistance in Campylobacter jejuni isolated from broiler carcasses in Belgium. Front. Microbiol., 9: 1014.

12. Ghunaim, H., Behnke, J.M., Aigha, I., Sharma, A., Doiphode, S.H. and Deshmukh, A. (2015) Analysis of resistance to antimicrobials and presence of virulence/stress response genes in Campylobacter isolates from patients with severe diarrhoea. PLoS One, 10(3): e0119268.

13. Kalantar, M., Dallal, M.M.S., Fallah, F. and Yektaei, F. (2017) Monitoring the virulence genes in Campylobacter coli strains isolated from chicken meat in Tehran, Iran. Infect. Epidemiol. Med., 3(1): 12-15.

14. Wilson, D.L., Rathinam, V.A., Qi, W., Wick, L.M., Landgraf, J. and Bell, J.A. (2010) Genetic diversity in Campylobacter jejuni is associated with differential colonization of broiler chickens and C57BL/6J IL10-deficient mice. Microbiology, 156(7): 2046-2057. 
15. Younis, G., Awad, A. and Khairy, M. (2018) Molecular characterization and virulence of Campylobacter jejuni isolated from broiler chickens. Int. J. Poult. Sci., 17(10): 499-506.

16. Penner, J.L. (1988) The genus Campylobacter: A decade of progress. Clin. Microbiol. Rev., 1(2): 157-172.

17. Modi, S., Brahmbhatt, M.N., Chatur, Y.A. and Nayak, J.B. (2015) Prevalence of Campylobacter species in milk and milk products, their virulence gene profile and anti-bio gram. Vet. World, 8(1): 1-8.

18. Wang, G., Clark, C.G., Taylor, T.M., Pucknell, C., Barton, C. and Price, L. (2002) Colony multiplex PCR assay for identification and differentiation of Campylobacter jejuni, C. coli, C. lari, C. upsaliensis, and C. fetus subsp. Fetus. J. Clin. Microbiol., 40(12): 4744-4747.

19. Da Frasao, B.S., Marin, V.A. and Conte-Junior, C.A. (2017) Molecular detection, typing, and quantification of Campylobacter spp. in foods of animal origin. Compr. Rev. Food Sci. Food Saf., 16(4): 721-734.

20. Konkel, M.E., Gray, S.A., Kim, B.J., Garvis, S.G. and Yoon, J. (1999) Identification of the enteropathogens Campylobacter jejuni and Campylobacter coli based on the cadF virulence gene and its product. J. Clin. Microbiol., 37(3): 510-517.

21. Bang, D.D., Neilsen, E.M., Scheutz, F., Pedersen, K., Handberg, K. and Madsen, M. (2003) PCR detection of seven virulence and toxin genes of Campylobacter jejuni and Campylobacter coli isolates from Danish pigs and cattle and cytolethal distending toxin production of the isolates. J. Appl. Microbiol., 94(6): 1003-1014.

22. Abd El-Tawab, A., Ammar, A., Ahmed, H., El Hofy, F. and Hefny, A. (2018) Bacteriological and molecular identification of some Campylobacter species in broilers and their macrolide resistance profile. Benha. Vet. Med. J., 34(1): 374-391.

23. Carrique-Mas, J.J., Bryant, J.E., Cuong, N.V., Hoang, N.V.M., Campbell, J. and Hoang, N.V. (2014) An epidemiological investigation of Campylobacter in pig and poultry farms in the Mekong delta of Vietnam. Epidemiol. Infect., 142(7): 1425-1436.

24. Mäesaar, M., Praakle, K., Meremäe, K., Kramarenko, T., Sõgel, J. and Viltrop, A. (2014) Prevalence and counts of Campylobacter spp. in poultry meat at the retail level in Estonia. Food Control, 44(1) 72-77.

25. Abushahba, M., Ahmed, S., Ibrahim, A. and Mosa, H. (2018) Prevalence of zoonotic species of Campylobacter in broiler chicken and humans in Assiut governorate, Egypt. Approaches Poult. Dairy Vet. Sci., 3(4): 1-9.

26. ELSayed, M., Tarabees, R., Shehata, A., Harb, O. and Sabry, A. (2019) Virulence repertoire and antimicrobial resistance of Campylobacter jejuni and Campylobacter coli isolated from some poultry farms in Menoufia governorate, Egypt. Pak. Vet. J., 39(2): 261-265.

27. Da Silva, D.T., Tejada, T.S., Blum-Menezes, D., Dias, P.A. and Timm, C.D. (2016) Campylobacter species isolated from poultry and humans, and their analysis using PFGE in southern Brazil. Int. J. Food Microbiol., 217 (1): 189-194.

28. Mdegela, R.H., Nonga, H.E., Ngowi, H.A. and Kazwala, R.R. (2006) Prevalence of thermophilic Campylobacter infections in humans, chickens and crows in Morogoro, Tanzania. J. Vet. Med. Ser. B, 53(3): 116-121.

29. Pezzotti, G., Serafin, A., Luzzi, I., Mioni, R., Milan, M. and Perin, R. (2003) Occurrence and resistance to antibiotics of Campylobacter jejuni and Campylobacter coli in animals and meat in Northeastern Italy. Int. J. Food Microbiol., 82(3): 281-287.

30. Salihu, M.D., Junaidu, A.U., Magaji, A.A. and Yakubu, Y. (2012) Prevalence and antimicrobial resistance of thermophilic Campylobacter isolates from commercial broiler flocks in Sokoto, Nigeria. Res. J. Vet. Sci., 5(2): 51-58.

31. Kalupahana, R.S., Kottawatta, K.S.A., Kanankege, K.S.T., van Bergen, M.A.P., Abeynayake, P. and Wagenaar, J.A. (2013) Colonization of Campylobacter spp. in broiler chickens and laying hens reared in tropical climates with low-biosecurity housing. Appl. Environ. Microbiol., 79(1): 393-395.

32. Chatur, Y., Brahmbhatt, M., Modi, S. and Nayak, J. (2014) Fluoroquinolone resistance and detection of topoisomerase gene mutation in Campylobacter jejuni isolated from animal and human sources. Int. J. Curr. Microbiol. Appl. Sci., 3(6): 773-783.

33. Bertasi, B., Losio, M.N., Daminelli, P., Finazzi, G., Serraino, A. and Piva, S. (2016) Seasonal variability of thermophilic Campylobacter spp. in raw milk sold by automatic vending machines in Lombardy. Ital. J. Food Saf., 5(3): 5848 .

34. Rahimi, E. and Tajbakhsh, E. (2008) Prevalence of Campylobacter species in poultry meat in the Esfahan city, Iran. Bulg. J. Vet. Med., 11(4): 257-262.

35. Di Giannatale, E., Di Serafino, G., Zilli, K., Alessiani, A., Sacchini, L. and Garofolo, G. (2014) Characterization of antimicrobial resistance patterns and detection of virulence genes in Campylobacter isolates in Italy. Sensors, 14(2): 3308-3322.

36. El-Zamkan, M.A. and Hameed, K.G.A. (2016) Prevalence of Campylobacter jejuni and Campylobacter coli in raw milk and some dairy products. Vet. World, 9(10): 1147-1151.

37. Mabote, K.I., Mbewe, M. and Ateba, C.N. (2011) Prevalence of Campylobacter contamination in fresh chicken meat and milk obtained from markets in the North-West Province, South Africa. J. Hum. Ecol., 36(1): 23-28.

38. Giacometti, F., Bonilauri, P., Serraino, A., Peli, A., Amatiste, S. and Arrigoni, N. (2013) Four-year monitoring of foodborne pathogens in raw milk sold by vending machines in Italy. J. Food Prot., 76(11): 1902-1907.

39. Singh, H., Rathore, R.S., Singh, S. and Cheema, P.S. (2011) Comparative analysis of cultural isolation and PCR based assay for detection of Campylobacter jejuni in food and faecal samples. Braz. J. Microbiol., 42(1): 181-186.

40. Sainato, R., ElGendy, A., Poly, F., Kuroiwa, J., Guerry, P. and Riddle, M.S. (2018) Epidemiology of Campylobacter infections among children in Egypt. Am. J. Trop. Med. Hyg., 98(2): 581-585.

41. Rouby, S., Abdel-Latef, G. and Aziz, S.A. (2019) Bacteriological and molecular identification of thermophilic Campylobacters of animal and human origins in Beni-Suef governorate, Egypty. J. Adv. Vet. Res., 9(3): 102-106.

42. Youseef, A., Ibrahim, A., Sayed, A. and Sobhy, M. (2017) Occurrence of Campylobacter species in chickens by multiplex polymerase chain reaction. Assiut. Vet. Med. J., 63(152): 66-72.

43. Jorgensen, F., Bailey, R., Williams, S., Henderson, P., Wareing, D.R.A. and Bolton, F.J. (2002) Prevalence and numbers of Salmonella and Campylobacter spp. on raw, whole chickens in relation to sampling methods. Int. J. Food. Microbiol., 76(1-2): 151-164.

44. El-Shibiny, A., Connerton, P. and Connerton, I. (2009) Survival at refrigeration and freezing temperatures of Campylobacter coli and Campylobacter jejuni on chicken skin applied as axenic and mixed inoculums. Int. J. Food. Microbiol., 131(2-3): 197-202.

45. Zbrun, M.V., Olivero, C., Romero-Scharpen, A., Rossler, E., Soto, L.P. and Astesana, D.M. (2015) Antimicrobial resistance in thermotolerant Campylobacter isolated from different stages of the poultry meat supply chain in Argentina. Food Control, 57(1) 136-141.

46. Udayamputhoor, R.S., Hariharan, H., Van Lunen, T.A., Lewis, P.J., Heaney, S. and Price, L. (2003) Effects of diet formulations containing proteins from different sources on intestinal colonization by Campylobacter jejuni in broiler chickens. Can. J. Vet. Res., 67(3): 204-212.

47. Omara, S.T., Fadaly, H.A. and Barakat, A.M.A. (2015) Public health hazard of zoonotic Campylobacter jejuni reference to Egyptian regional and seasonal variations. Res. J. Microbiol., 10(8): 343-354. 
48. Grzybowska-Chlebowczyk, U., Kalita, B., Flak-Wancerz, A., Jasielska, M. and Więcek, S. (2013) Clinical course of Campylobacter infections in children. Pediatr. Pol., 88(4): 329-334.

49. Gharst, G., Oyarzabal, O.A. and Hussain, S.K. (2013) Review of current methodologies to isolate and identify Campylobacter spp. from foods. J. Microbiol. Methods, 95(1): 84-92.

50. Abu-Madi, M., Behnke, J.M., Sharma, A., Bearden, R. and Al-Banna, N. (2016) Prevalence of virulence/stress genes in Campylobacter jejuni from chicken meat sold in Qatari retail outlets. PLoS One, 11(6): e0156938.
51. Al Amri, A., Senok, A.C., Ismaeel, A.Y., Al-Mahmeed, A.E. and Botta, G.A. (2007) Multiplex PCR for direct identification of Campylobacter spp. in human and chicken stools. $J$. Med. Microbiol., 56(10): 1350-1355.

52. Gonzalez-Hein, G., Huaracan, B., Garcia, P. and Figueroa, G. (2014) Prevalence of virulence genes in strains of Campylobacter jejuni isolated from human, bovine and broiler. Braz. J. Microbiol., 44(4): 1223-1229.

53. Wysok, B., Uradziński, J., Wojtacka, J. (2015) Determination of the cytotoxic activity of Campylobacter strains isolated from bovine and swine carcasses in North-Eastern Poland. Pol. J. Vet. Sci., 18(3): 579-586.

$* * * * * * * *$ 